\title{
温度センサーTRPチャネルの生息環境に虑ざ機能進化也 その構造基盤
}

\section{齋藤 茂 ${ }^{1,2}$, 富永真琴 1,2}

'生理学研究所·細胞生理研究部門

${ }^{2}$ 生命創成探究センター・温度生物学研究グループ

\begin{abstract}
Thermal perception is an essential physiological system for responding to ambient temperature fluctuations, and thus likely plays crucial roles in evolutionary adaptation. Thermosensitive transient receptor potential (thermoTRP) channels serve as temperature sensors. They are multimodal receptors that are activated by thermal stimuli as well as various chemicals. The properties of thermoTRP channels have varied among diverse animal species. In addition, comparative analyses among closely related species inhabiting different thermal niches revealed that property of thermoTRP channels changed during adaptation processes. Here we introduce evolutionary changes and their structural basis for the functional diversity of thermoTRP channels.
\end{abstract}

thermal perception / heat sensors / thermosensitive TRP channels / adaptation / structural basis / vertebrates

1.

はじめに

動物は環境の温度を鋭敏に感じとり，その変化に対 して生理的・行動的に応答し，生体恒常性を維持して いる. 地球上には様々な温度条件の環境が存在するが, それぞれの動物種は形態や生理的な特性を変化させて, 進化の過程で多様な環境に適応してきた。異なる温度 環境に生息する種の間では生存に適した温度域が異な ることがあるが，そらいった動物種の間では温度の感 じ方「温度感覚」もまた進化の過程で変化してきたの ではないだろらか、そのような観点から著者らはこれ まで，多様な動物種を対象にした比較解析を進めてき た．本総説では，温度受容のセンサー分子として働く 温度感受性 TRP チャネルの種間比較により明らかと なったチャネル機能の多様性とその構造基盤，また， 環境適応との関連性について最新の知見を紹介する.

2. 温度受容の分子機構

動物は体表の温度変化を通して外界の温度を感知し ている．表皮下に分布する感覚神経の末端に発現する 温度感受性のイオンチャネルが温度受容体として働い ており，多くが transient receptor potential (TRP) ファ ミリーに分類される非選択性陽イオンチャネルであ る.マウスやヒトなどの哺乳類では 11 種類の温度感 受性 TRPチャネルが同定されている ${ }^{1), 2)}$ (TRP vanil- loid 1, V2, V3, V4; TRP Melastatin 2, M3, M4, M5, M8; TRP Ankyrin 1; TRP Canonical 5). 温度感受性 TRP チャ ネルはそれぞれ固有の温度受容域を持っている。例え ば，ヒトやマウスでは TRPV1は熱刺激に対して約 $42^{\circ} \mathrm{C}$ 以上の高温で活性化され，TRPV3 や TRPV4 は $27 \sim 33^{\circ} \mathrm{C}$ 以上の体温に近い温かい温度で活性化され る. 一方で, TRPM8 は $25 \sim 28^{\circ} \mathrm{C}$ 以下の冷涼な温度 で，TRPA 1 は $17^{\circ} \mathrm{C}$ 以下の低温で活性化される。これ らの TRP チャネルの顕著な特性として 1 種類のチャ ネルが多様な感覚刺激により活性化されることが挙げ られる。例えば，TRPV1は熱だけでなく，カプサイ シンや酸刺激により，また，TRPA1 はワサビの辛み 成分であるアリルイソチオシアネートや，他にも様々 な植物に含まれる化学物質によって活性化される。こ のように温度感受性 TRPチャネルはマルチモーダル な感覚刺激の受容体として機能している。これらの チャネルは感覚神経だけでなく，全身の様々な組織に 分布して打り，温度感覚以外にも多様な組織や細胞に 掞いて温度に関連した生理機構に関わっている ${ }^{1)}$.

TRPチャネル全体の立体構造は長らく解かれていな かったが，低温（クライオ）電子顕微鏡を用いた単粒 子解析により TRPV1 や TRPA1 の詳細な構造が報告さ れた ${ }^{3)-5)}$. 1 つのサブュニットは 6 個の膜貫通ドメイ ンを有し，4量体の中央にイオンを透過するポアが形 成される (図 1 $)^{3)}$. TRPV1 のアゴニストであるカプ サイシンは第 3 および第 4 膜貫通ドメインに位置する

Functional Changes and Their Structural Basis for Thermal Sensor TRP Channels Related to Evolutionary Adaptation

Shigeru SAITO ${ }^{1,2}$ and Makoto TOMINAGA ${ }^{1,2}$

${ }^{1}$ Division of Cell Signaling, National Institute for Physiological Sciences

${ }^{2}$ National Institutes of Natural Sciences 
A

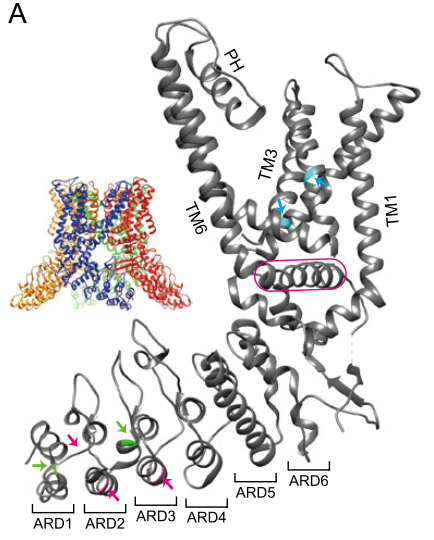

B

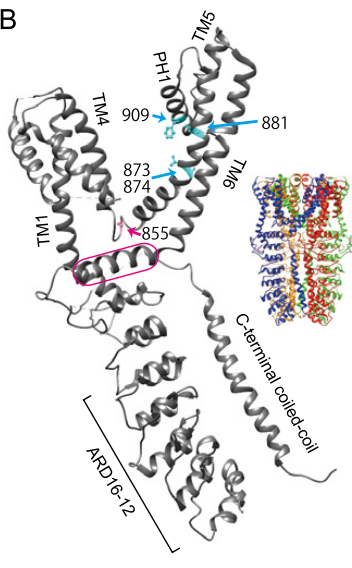

要

TRPV1 と TRPA1 の立体構造. TRPV1（A）とTRPA1（B）の各サブ ユニットと 4 量体の立体構造を示した. TRPV1 のカプサイシン結 合の種間差に関わるアミノ酸をシアンで，ツメガエルまたはジリ スの TRPV1 の温度応答性に関与するアミノ酸をそれぞれマゼンタ と緑で示した. TRPA1 のA-967079 およびHC-030031 の結合に関 与するアミノ酸をシアンとマゼンタで示した. 数字はアミノ酸の 位置を示す. TM:膜貫通ドメイン, PH:ポアヘリックス, ARD:ア ンキリンリピートドメイン. TRP ドメイン（A）およびTRP-like ド メイン（B）をマゼンタの線で囲っている. 文献 18 から改変引用.

アミノ酸で構成されるポケットに結合し，ポアを開口 させる ${ }^{4)}$. 各サブュニットの $\mathrm{N}$ および C末端領域は 細胞内に位置している (図 1 ${ }^{3)}$,4)。TRPV1 の $\mathrm{N}$ 末端 側のアンキリンリピートドメインには，活性を増強さ せるATPや，反対に活性を低下させるカルモジュリ ンが結合する ${ }^{6)}$. TRPチャネルの立体構造が解明され たことにより，チャネル機能に関与するアミノ酸の役 割を構造的な側面から解釈することが可能となった。

3. 温度感受性TRPチャネルの種間多様性と構造基盤

TRPV1 や TRPA1 は感覚神経に共発現し，痛みとし て認識される化学物質や温度によって活性化されるこ とから，組織や生体を損傷し得る侵害刺激の受容に関 わっている。 TRPA1 はヒトを含む脊椎動物から昆虫 などの無脊椎動物まで共有されて拈り，進化的に起源 が古いチャネルである ${ }^{2)}$. ヒトやマウスの TRPA1 は 前述の通り低温で活性化されると報告されているのだ が，ヒトやマウスの TRPA1 の温度感受性については 未だに統一した見解が得られていない。我々は複数の 脊椎動物種（グリーンアノールトカゲ，ツメガエル， ニワトリ）扣よび無脊椎動物（ヒトデ）の TRPA1が 高温または温かい温度によって活性化されることを明 らかにした ${ }^{7-9)}$. TRPA1 はショウジョウバエや蚊など の昆虫でも温かい温度で活性化されることが知られて いる。 また，ワサビに含まれるアリルイソチオシア ネートのよらな化学物質の感受性は昆虫から哺乳類の TRPA1 まで広く保存されている，これらを考慮する
と TRPA1 は動物の初期の進化過程で獲得され，高温 (または温かい温度）および化学物質の受容体として 機能していたと考えられる2)。一方，TRPV1 は脊椎動 物の祖先種で新たに生じた遺伝子であり，脊椎動物種 に共有されていることが我々の分子系統学的な解析に より示されている ${ }^{10)}$. TRPV1 は哺乳類, 鳥類, 爬虫 類，両生類，魚類などの多くの脊椎動物種に拈いて高 温により活性化される2),11), 12). 脊椎動物の祖先にお いて既存の TRPA1 に加えて，新たに TRPV1 が獲得さ れ，侵害受容に関わるチャネルのレパートリーが増加 したと考えられる.

TRPA1の阻害剂は鎮痛薬としての利用が期待され 複数のアンタゴニストがマウスやヒトなどの TRPA1 を用いて同定されてきた，我々はこれらの化学物質 の作用が哺乳類以外の脊椎動物では異なることを見出 した。 分子構造が類似するAP-18 とA-967079は哺乳 類 TRPA1 を阻害するが，グリーンアノールトカゲの TRPA1 に対しては全く作用しない.さらに，これら の化学物質はニワトリ拈よびネッタイッメガエルの TRPA1 を活性化させる ${ }^{13)}$. TRPA1の種間比較により， ヒトの TRPA1 の第 5 膜貫通ドメインの 881 番目のロ イシン（L881）が AP-18 とA-967079 による阻害作用に 大きな役割を担らことを明らかにした（図 1)。ヒト TRPA1の 881 番目に対応するアミノ酸はニワトリの TRPA1 ではイソロイシンになっており，ヒト TRPA1 の 881 番目のロイシンをイソロイシンに変化させると A-967079により活性化されるよらになる ${ }^{13)}$ 。後に報 告されたヒトTRPA1 の立体構造では，A-967079は第 5 膜貫通ドメインとポアヘリックスに結合し，L881 は結合部位に位置するアミノ酸であることが報告され た 。他にもヒト TRPA1 の 873，874，909番目のアミ ノ酸は結合部位に位置しており，電気生理学的な解析 によりA-967079の作用に関与することが知られてい $ろ^{5), 14), 15)}$.A-967079の結合部位はチャネルポアに近い 位置にあるために，この化学物質は楔のような働きを してヒト TRPA1 の活性を抑制すると推測されている.

一方で，HC-030031 は哺乳類，ニワトリ，グリーン アノールの TRPA1 の活性を抑制するが，ネッタイッ メガエルとゼブラフィッシュの TRPA1を抑制しない. これらの種間比較を通してヒト TRPA1の855番目の アスパラギン（N855）が HC-030031 の阻害効果に関 与することを明らかにした ${ }^{16)}$ (図 1). 分子動態シミュ レーションの結果，このアミノ酸の側鎖はHC-030031 と水素結合を形成することが示唆された。N855 は立 体構造では TRP-likeドメインの近傍に位置する。こ のドメインは膜貫通ドメインと細胞内のアンキリンリ ピートドメインやC末端側の領域との相互作用に関 与寸ると考觉られている. このよらにN855 は立体構 造上の位置が A-967079 の結合部位とは異なっており， 
二つのアンタゴニストは別々の分子機構で TRPA1の 活性を抑制すると考觉られる ${ }^{16)}$.

4 .

\section{環境適応に関連した温度感受性 TRP チャネルの 機能進化}

TRPA1の温度感受性は動物種間で異なって括り, それらはそれぞれの種の生態的および生理的な特性と 関連していると期待される。しかし，系統的に遠縁な 動物種間では特性が大きく異なるため，温度感受性 TRPチャネルの機能变化と環境適応を結び付けるこ とができなかった。そのよらな課題に取り組むために は異なる温度条件の環境に生息する近縁な種間の比較 が有用であり，筆者らはツメガエル種を用いた研究を 行った ${ }^{17)}$.アフリカツメガエルとネッタイツメガエル は近縁種であり，成体も水中で生活するなど生態的お よび生理的な特性が類似している。両種はアフリカに 分布し，ネッタイッメガエルは一般的にアフリカッメ ガエルよりも暑い地域に生息し, 飼育に適した温度域 も前者の汪らが高い(図 2).

これら 2 種の高温刺激に対する逃避行動を比較した ところ，ネッタイツメガエルはアフリカツメガエルよ りも $2^{\circ} \mathrm{C}$ ⿷ど高い温度から逃避行動を示すことが分 かった（図 2)。また，感覚神経である後根神経節細胞 の活性化温度の閾值もネッタイッメガエルは $2^{\circ} \mathrm{C}$ ほど 高かった。 そこで，高温センサーとして働くTRPA1

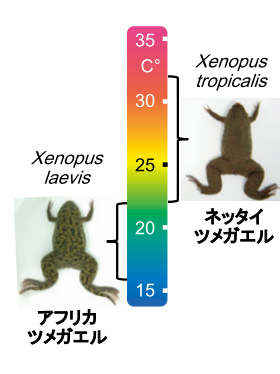

高温刺激に対する応答の比較

\begin{tabular}{|c|c|c|c|}
\hline & & $\begin{array}{c}\text { アフリカ } \\
\text { ッメガエル }\end{array}$ & $\begin{array}{c}\text { ネッタイ } \\
\text { ツメガエル }\end{array}$ \\
\hline 逃避行重 & & $>38^{\circ} \mathrm{C}$ & $>40^{\circ} \mathrm{C}$ \\
\hline 感覚神経 & (後根神経節) & $>36^{\circ} \mathrm{C}$ & $>38^{\circ} \mathrm{C}$ \\
\hline TRPA1 & $\begin{array}{l}\text { 温度閾值a } \\
\text { 活性 }\end{array}$ & $\begin{array}{l}>38^{\circ} \mathrm{C} \\
\text { 高い }\end{array}$ & $\begin{array}{l}>40^{\circ} \mathrm{C} \\
\text { 低い }\end{array}$ \\
\hline TRPV1 & $\begin{array}{l}\text { 温度閾値a } \\
\text { 反応性 }\end{array}$ & $\begin{array}{l}>41^{\circ} \mathrm{C} \\
\text { 速い }\end{array}$ & $\begin{array}{l}>41^{\circ} \mathrm{C} \\
\text { 遅い }\end{array}$ \\
\hline
\end{tabular}

図 2

2 種のツメガエルの比較. 2 種のツメガエルの飼育に適した温度 域 (左) と高温刺激に対する応答性の比較（右).

およびTRPV1の比較解析を行った. TRPA1の高温刺 激に対する活性はネッタイツメガエルの注らが低く, 一方で活性化温度の閾值はアフリカッメガエルに比べ てネッタイッメガエルの汪らが $2^{\circ} \mathrm{C}$ 汪ど高かった（図 3A-D).

TRPV1 については繰り返しの熱刺激を加えた場合 にネッタイッメガエルでは徐々に反応が大きくなるの に対して，アフリカッメガエルでは 1 回目から浪最 大の応答を示した（図 3E)。さらに，2 種間の TRPV1 のキメラチャネルや突然変異体チャネルを用い, アン キリンリピートドメイン 2-3 の中に位置する 3 つのア ミノ酸置換が熱刺激応答の種間差に関与することを明 らかにした ${ }^{17)}$ (18) (図 1)。これらの観察結果から 2 種 のツメガエルは異なる温度環境に適応する過程で高温

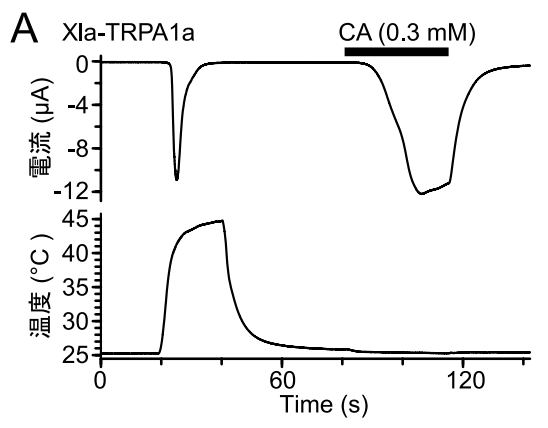

C

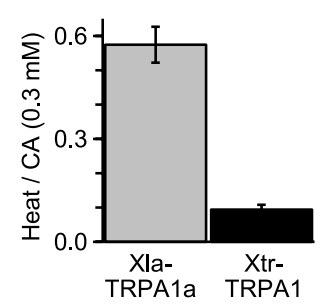

B Xtr-TRPA1

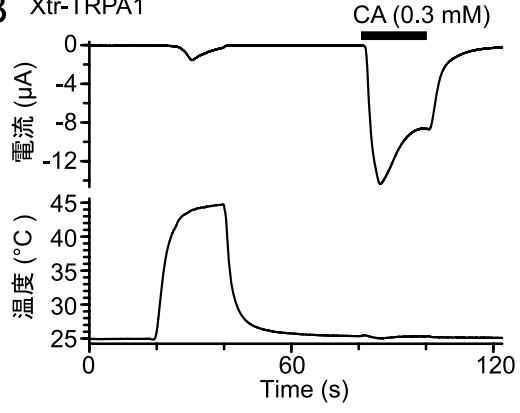

$E$

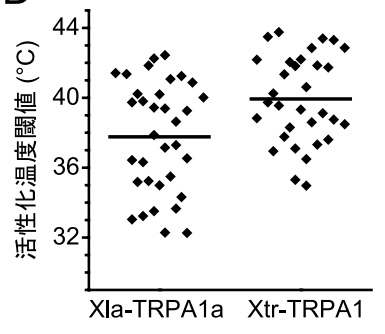

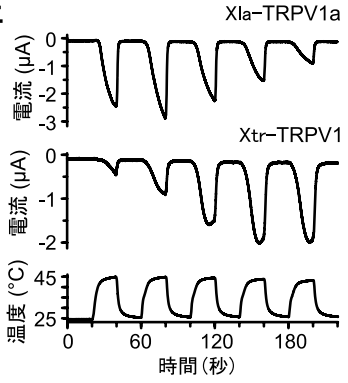

図 3

2 種のツメガエルの高温センサーの種間差. アフリカツメガエル（A， Xla） とネッタイツメガエル（B， Xtr）の TRPA1 の熱刺激およびシンナ ムアルデヒド（CA）に対する応答を示した. TRPA1 の熱刺激に対する活性の比較（C). 熱刺激で生じた電流值をCAによる電流值で標準化 した. TRPA1 の活性化温度闇值の比較 (D). TRPA1 を発現する卵母細胞から得られた值を点で, 平均值を線で表示した. TRPV1の繰り返し 熱刺激に対する応答性の種間差（E）．各種のTRPA1 またはTRPV1 をアフリカツメガエル卵母細胞に強制発現させて， 2 電極膜電位固定法で イオン電流を測定した. 文献 17 から改変引用. 
センサーのチャネル機能を変化させてきたと考えられ る ${ }^{18)}$ (図 2).

爬虫類に打いても生息する環境に応じてTRPA1の 機能が変化しているかを検討した ${ }^{19)}$. キューバに分布 する近縁な 3 種のアノールトカゲは同所的に生息して いるが, Anolis allogus は森林内部に，Anolis homolechis は 森林の周縁部, Anolis sagrei は開けた環境に適応してい る. A. allogusは日光にあまり暴露されないのに対して, 残りの 2 種は日光に当たることで体温を調節する. 温 度上昇時の逃避温度を比較したところ，A. allogus は他 の 2 種に比べてより低い温度から逃避行動を示した. さらに，TRPA1の活性化温度の閾值もA. allogus は他 の 2 種に比べて低かった.

哺乳類においても TRPV1の機能変化が環境適応と 関連することをL Laursen らが報告している20). ジリス の一種は高温耐性を有して批り，TRPV1の高温応答 性が著しく低下している，興味深いことに，砂漠のよ らな高温環境に適応しているラクダでも TRPV1の高 温応答が失われている。それぞれの系統でTRPV1の 温度刺激に対する活性が低下寸る進化的な変化が独立 に生じたと考えられる。TRPV1の高温に対する活性 の減弱にはアンキリンリピートドメインに位置する 2 つのアミノ酸が関わることが示されている ${ }^{20)}$ (図 1).

5.

$$
\text { 今後の課題と展望 }
$$

近縁種間の比較により，生息する環境の温度条件に 応じて温度感受性 TRP チャネルの特性が柔軟に変化 してきたことが明らかとなった.さらに、ツメガエル とジリスの TRPV1 では種間差に関わるアミノ酸置換 がアンキリンリピートドメインに生じていた ${ }^{17), 20)}$. しかし，ジリスの研究例に扣いて同定されたアミノ酸 置換は，比較対象に用いられたマウスの系統で独自に 生じたことが分かっている ${ }^{20)}$. 高温耐性の上昇と関連 していた場合は, TRPV1のアミノ酸の変化はジリス に至る系統で生じたはずである。 また，ツメガエルの 例では 2 種の比較に留まっているために, TRPV1や TRPA1の機能変化がぞの系統で生じたのかが未解明 である ${ }^{17)}$. このように環境適応に関連した分子基盤を 理解するためには動物種の系統関係を考慮する必要が ある．現在，異なる温度環境に生息する複数の両生類 種を用いた比較解析を進めており, 環境適応に関連し た温度受容システムの変化やその分子基盤を進化的な 背景を含めて明らかにする研究を展開していきたい.

\section{文 献}

1) Julius, D. (2013) Annu. Rev. Cell Dev. Biol. 29, 355-384. DOI: 10.1146/annurev-cellbio-101011-155833.

2) Saito, S., Tominaga, M. (2015) Cell Calcium 57, 214-221. DOI: 10.1016/j.ceca.2014.12.001.

3) Liao, M. et al. (2013) Nature 504, 107-112. DOI: 10.1038/ nature12822.

4) Cao, E. et al. (2013) Nature 504, 113-118. DOI: 10.1038/ nature12823.

5) Paulsen, C. E. et al. (2015) Nature 520, 511-517. DOI: 10.1038/ nature14367.

6) Lishko, P. V. et al. (2007) Neuron 54, 905-918. DOI: 10.1016/ j.neuron.2007.05.027.

7) Saito, S. et al. (2014) Mol. Biol. Evol. 31, 708-722. DOI: 10.1093/ molbev/msu001.

8) Saito, S. et al. (2012) J. Biol. Chem. 287, 30743-30754. DOI: 10.1074/jbc.M112.362194.

9) Saito, S. et al. (2017) Sci. Rep. 7, 2173. DOI: 10.1038/s41598-01702171-8.

10) Saito, S., Shingai, R. (2006) Physiol. Genomics 27, 219-230. DOI: 10.1152/physiolgenomics.00322.2005.

11) Ohkita, M. et al. (2012) J. Biol. Chem. 287, 2388-2397. DOI: 10.1074/jbc.M111.305698.

12) Gau, P. et al. (2013) J. Neurosci. 33, 5249-5260. DOI: $10.1523 /$ JNEUROSCI.5403-12.2013.

13) Banzawa, N. et al. (2014) J. Biol. Chem. 289, 31927-31939. DOI: 10.1074/jbc.M114.586891.

14) Nakatsuka, K. et al. (2013) J. Mol. Neurosci. 51, 754-762. DOI: 10.1007/s12031-013-0060-2.

15) Xiao, B. et al. (2008) J. Neurosci. 28, 9640-9651. DOI: 10.1523/ JNEUROSCI.2772-08.2008.

16) Gupta, R. et al. (2016) Sci. Rep. 6, 37460. DOI: 10.1038/ srep37460.

17) Saito, S. et al. (2016) J. Biol. Chem. 291, 11446-11459. DOI: 10.1074/jbc.M115.702498.

18) Saito, S., Tominaga, M. (2017) Temperature (Austin) 4, 141-152. DOI: $10.1080 / 23328940.2017 .1315478$.

19) Akashi, H. D. et al. (2018) Mol. Ecol. 27, 2234-2242. DOI: 10.1111/mec.14572.

20) Laursen, W. J. et al. (2016) Proc. Natl. Acad. Sci. USA 113, 1134211347. DOI: $10.1073 /$ pnas. 1604269113.

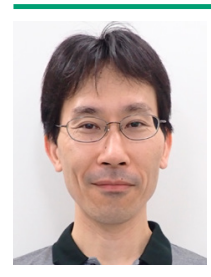

齋藤 茂

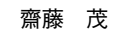

べている。

連絡先: $=$ 444-8787 愛知県岡崎市明大寺町字東 山 5-1

E-mail: sshigeru@nips.ac.jp URL: http://www.nips.ac.jp/cs/

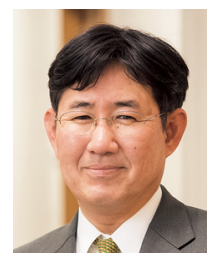

富永真琴 て温度受容や侵害刺激受容の分子メカニズムを研

\section{富永真琴（とみなが まこと）}

生理学研究所・生命創成探究センター教授

愛媛大学医学部卒, 京都大学大学院医学研究科博 士課程修了, 生理学研究所助手, UCSF 博士研究 員, 筑波大学講師, 三重大学教授を経て現職. 研究内容: 温度感受性 TRP チャネルに焦点をあて 究している。

連絡先:同上

E-mail: tominaga@nips.ac.jp URL: http://www.nips.ac.jp/cs/ 